\title{
INTERCULTURAL COMMUNICATION AND CROSS-CULTURAL MANAGEMENT IN UKRAINE
}

\author{
Kaplina A. I.
}

\section{INTRODUCTION}

The relevance of the multi-agent system is due to the following main reasons: the complexity of modern systems and organizations, which reaches such a level that centralized management in them is ineffective due to the presence of large flows of information.

Cross-cultural aspects of recruitment, selection and adaptation of personnel distinguish the following varieties of international policy in multinational companies ethnocentric policy: filling key positions in their representative offices of the world only by personnel from the country of the parent company; polycentric policy: the use of local residents to manage foreign representative offices and managers from the parent company's countries as top managers of the company's headquarters; geocentric policy: to recruit the best and develop personnel, independence from nationality, to key positions in any multinational system.

The article discusses an attempt to analyze the basic principles of crosscultural personnel management, which can be used when writing textbooks or in the work of HR managers. To implement management technologies today, the employee of the company must have cross-cultural achievements, that is, the ability in someone else's and mixed cultural environment to demonstrate consistent behavior that leads to achieving the goals. Human resources management of an organization operating in several countries, in a mixed or diverse cultural environment, aims to analyze the cultural impact on the main areas of organizational behavior and personnel management functions: organizational culture and structure; organizational communications; conflicts in the organization; motivation of staff; selection and adaptation, training of staff.

Recently, the systematic establishment relations between Ukraine and China has become increasingly significant. In this regard, ethnocultural differences, which are at the root business relations between different companies, are great importance. Today, there is a large amount of infusion Chinese investments into the Ukrainian economy, as a result of close cooperation it is necessary to try to achieve mutual understanding and mutual permeability and complement economies between the countries. The effectiveness these relations determines the need to take into account the 
phenomenon of cross-cultural management in the construction of business relations. The most important task in the current conditions is the study and application of Confucian ethics, taking into account its impact on the culture and business traditions of negotiations will allow to intensify the decisionmaking process in international business. As a result of the globalization of the world economy, in which representatives of different cultures are involved, it is necessary to try to increase the range of business contacts in the world market, expand investments abroad, increase the overall culture when working in a cross-cultural environment, build an adaptive management system based on the study of the experience of the world's best companies. For a clear organization work, it is necessary to keep records all the nuances that can manifest themselves in joint production when making management decisions with representatives different cultures.

\section{Cross-cultural management, a tool for organizing the cross-cultural interaction}

Cross-cultural interaction is an important problem of today: business ties are expanding, multinational management teams are being formed, multinational companies are developing, international social associations are being created, intercultural ties are growing. This problem received a scientific production in the nineties, the concept of intercultural interaction was developed, the subject branch of comparative and cross-cultural management was determined, the main models of cross-cultural interaction were developed. However, there are no clear definitions and areas of scientific research of cross-cultural interaction and a general approach to modeling cross-cultural interaction ${ }^{1}$. This gender presents the subject areas of international, comparative and cross-cultural management and defined cross-cultural interaction modelling based on the tools of multi-agent systems.

The main cultural interest in the problem of cross-cultural management arose in Europe and the USA in the late 80s and early 90s, when the main researches of the Dutch G. Hawkstead and F. Trompenaars ${ }^{2}$ and the American Nigel Holden ${ }^{3}$ were published which today became classics and authorities of cross-cultural management. Today, the works of some Russian

${ }^{1}$ Black J. and Mendenhall M. (1990), "Cross-culture training effectiveness: a revive and theoretical framework for future research", Academy of Management Review, Vol. 15. Pp. 1131-1136.

${ }^{2}$ Evans S. (1992), "Conflict can be positive”, HR Magazine, Vol. 37 (5). pp. 49-51.

${ }^{3}$ Laurent A. (1986), "The Cross-cultural Puzzle of International Human Resources Management”, Human Resources Management, Vol 25 (1). Pp. 91-102. 
and Ukrainian scientists, in particular L. Borisova ${ }^{4}$, S. Myazoedova, Y. Petrushchenko ${ }^{5}$, O. Romanukha ${ }^{6}$, are devoted to the analysis of national business cultures according to the classification parameters of the abovementioned models.

This publication aims at systematization of branches of knowledge of cross-cultural directions of modern management, determination of their subject industries and spheres of application. Development of the theory of multi-agent systems for modeling the behavior of multicultural management systems. On the basis of logical analysis, subject areas of new directions of mending, formalized task of intercultural interaction and possibility of modeling complex organizational systems ${ }^{2}$.

The emergence of international management in the 1990s is determined by the emergence of new problems of managing large international companies with multinational staff. Organization of corporate work of personnel with different cultural parameters requires determining patterns of interaction in a multinational environment. Cross-cultural interactions touch on the problems of group dynamics, accounting of national traditions and differences in culture. Comparative and cross-cultural management were distinguished into different sections - these courses began to be studied in the training programs of managers ${ }^{3}$. These new sections of management are applied in nature and various subjects and areas of application of knowledge (Table 1).

Different social systems have different priorities of life, activity, different mentality, different culture of individuals and organizations. Therefore, contacts of representatives of different cultures and systems may have different results. For example, an individual I1 with culture K1 may, as result of sociocultural differences, misunderstand actions and information (I21) from the second individual I2. There may be a barrier of misunderstanding or cross-cultural shock. If the mentalities M1 and M2 have little in common, then the difficulties of interaction will increase compared to those prepared for interaction by individuals ${ }^{4}$.

\footnotetext{
${ }^{4}$ Bunina V. (2008), "Cross-cultural management and intercultural kommunikia”, GUU.

${ }^{5}$ Holden N. (2005), "Cross-cultural management. Conception of cognative management", Uniti-Dana, pp. 364.

${ }^{6}$ Petrushenko $\mathrm{Yu}$ (2009), "Cross-cultural aspects of improving the efficiency of international business", Bulletin of Khmelnitsky National University, Vol. 5. URL: http://journals.khnu.km.ua/vestnik/pdf/ekon/2009_5_1/pdf/146-148.pdf. 17.09.2020).

(Accessed
} 
Subject areas of new sections of management

\begin{tabular}{|l|l|l|}
\hline \multicolumn{1}{|c|}{$\begin{array}{c}\text { Management } \\
\text { Section }\end{array}$} & \multicolumn{1}{c|}{$\begin{array}{c}\text { Subject } \\
\text { of study }\end{array}$} & \multicolumn{1}{c|}{$\begin{array}{c}\text { Application } \\
\text { branch }\end{array}$} \\
\hline $\begin{array}{l}\text { International } \\
\text { management }\end{array}$ & $\begin{array}{l}\text { Processes of management } \\
\text { of activities of } \\
\text { international companies }\end{array}$ & $\begin{array}{l}\text { Study of management } \\
\text { and organizational } \\
\text { relations in } \\
\text { international } \\
\text { companies, accounting } \\
\text { of cultural } \\
\text { characteristics of } \\
\text { personnel }\end{array}$ \\
\hline $\begin{array}{l}\text { Comparative } \\
\text { management }\end{array}$ & $\begin{array}{l}\text { National management } \\
\text { models, cultural and } \\
\text { institutional features of } \\
\text { countries, similarity of } \\
\text { management systems, } \\
\text { separation of the best } \\
\text { management techniques } \\
\text { and technologies }\end{array}$ & $\begin{array}{l}\text { Adaptation of } \\
\text { management methods } \\
\text { to cultural } \\
\text { characteristics of } \\
\text { countries, } \\
\text { development of } \\
\text { effective management } \\
\text { systems, separation of } \\
\text { best practices and } \\
\text { technologies }\end{array}$ \\
\hline $\begin{array}{l}\text { Cross-cultural } \\
\text { management }\end{array}$ & $\begin{array}{l}\text { Definition and } \\
\text { identification of socio- } \\
\text { cultural features in the } \\
\text { practice of managing } \\
\text { multinational collectives } \\
\text { of enterprises and } \\
\text { organizations }\end{array}$ & $\begin{array}{l}\text { Formation and } \\
\text { management of } \\
\text { multinational groups } \\
\text { on the basis of } \\
\text { accounting for cultural } \\
\text { characteristics and } \\
\text { mentality of workers }\end{array}$ \\
\hline
\end{tabular}

Comparative management studies the features of management systems of different countries and develops methods for increasing the effectiveness of interaction between representatives of rhine crops and the formation of management systems adequate to the mentality of the nation. The subject branch of comparative management consists of: analysis of the peculiarities of management and management of nations; diagnostics of organizing; features of the philosophy of the company and activity; business communication of representatives of different cultures; compliance with the management mentality; adaptation to another orgculture; methods of harmonization of orgcultures; management of organizing. 
The concept of comparative management states that success in solving the problems of business cooperation is possible based on an understanding of the culture and mentality of business partners and adaptation to their features ${ }^{7}$.

Formally, the study of cross-cultural interaction can be built on the positions of the theory of multiagent systems. Multi-agent systems formed from interacting intelligent agents achieve their own goals taking into account sociocultural statements, can be used to solve problems of cross-cultural interaction. Each agent is treated as a member of a group or organization. Task allocation involves determining the role of each member of the group, determining the extent of its responsibility and behavior requirements in the group. On this basis, you can build an expert system working on the basis of the rules of appearance: if (the situation $\mathrm{C} 1$ and the partner perform the actions of type D11), then perform actions (D22 with chances of W1 or actions D23 with chances of success of the W2), otherwise if the partner performs the D22 action with the W3 otherwise if (situation Sk, then perform Due), etc ${ }^{4}$.

The concept of comparative management is a focus on the culture and mentality of partners, which is supported by knowledge and methods of interaction with other cultures. At the same time, the principle of partner sovereignty is implemented, that is, it is necessary to focus on its features to the maximum extent. Comparative management is based on social and ethical management.

Formally, the process of interaction of agents can be described by the following components:

$$
\mathrm{Ma}=(\mathrm{S}, \mathrm{K}, \mathrm{R}, \mathrm{A}, \mathrm{I}, \mathrm{T}, \mathrm{U})
$$

where $\mathrm{S}$ is the set of agents of the management process; $\mathrm{K}$ is a division of the control system in which this process takes place; $\mathrm{R}$ - relationships created for agents (horizontal and vertical); A - a set of actions performed by agents; I - a set of established types of communication and interactions between agents; $\mathrm{T}$ - normative work technology; $\mathrm{U}$ - the state of achievement of the goals.

The process as a modeling object is dynamic. On the basis of the formal definition of the management system, it is possible to create an environment (virtual organization $\mathrm{K}$ ), which implements the relationships necessary to achieve the goals of the organization (U...) and take into account restrictions

${ }^{7}$ Romanukha O. (2017), "The role of cross-cultural communications in the management of organizations", Economics and society. Vol. 9. URL: http:// www.economyandsociety.in.ua/journal/9_ukr/103.pdf (Accessed 17.09.2020). 
in the form of sociocultural differences of agents (L) and (P). Such an environment can only be built on the basis of an agent-oriented approach that uses the placement of artificial intelligence ${ }^{5}$.

Cooperative activity is the basis of modern management, the problems of group work in companies are closely related to the problems of their internal organization. The more activities of the company, the more complex the products it produces, the greater the role of group work and the more highly organized the company should be. At the same time, more organized company, more independent its internal divisions should be, more rigid the directive management in its internal functioning is replaced by cooperation.

\section{Cross-cultural aspects of human resources management}

In management theory, it is determined that national culture is an important factor that determines the specifics of organizational behavior and development, the role of the manager in the organization, the nature of communication with employees and the style of decision-making in the company. Belonging of an employee of an organization to a certain cultural group affects how he interacts with others in conditions of subordination, collegiality and conflicts in all these relationships, three issues are important:

1. When factors of cultural affiliation are crucial for choosing a model of behavior?

2. When do other factors matter more?

3. How can we determine the significance of these factors for specific situations?

In order to answer these questions, it is necessary to analyze the phenomenon of organizational behavior in terms of cultural influence. Understanding the cultural specifics of organizational behavior helps the manager to make the right choice of personnel management technologies in the company ${ }^{8}$.

The modern Ukrainian HR manager does not have scientific and practical tools for diagnosing and managing intercultural differences in the company. Scientific literature devoted to cross-cultural management of personnel is presented in English and has not been translated into Ukrainian. In modern bookstores there is no literature devoted to the peculiarities of negotiations with representatives of different cultures or organization of personnel management of the company in the conditions of another subculture, means of adaptation of employees sent to work abroad.

${ }^{8}$ Kaplina A. and Kyrychenko N. (2020), "Cross-cultural aspects of human resources management", Efektyvna ekonomika. Vol. 10. URL: http://www.economy.nayka.com.ua/ ?op=1\&z=8258 (Accessed 03.11.2020). 
In this sex, an attempt is made to analyze the basic principles of crosscultural personnel management, which can be used in writing textbooks or in the work of HR managers.

Presentation of the main research material. For an objective assessment of the cultural impact on organizational behavior and personnel management, it is necessary to consider the results of studies conducted in different countries over the past ten to fifteen years.

To implement management technologies today, an employee of the company must have cross-cultural skills, that is, the ability in someone else's and mixed cultural environment to demonstrate consistent behavior that leads to the achievement of goals. Cross-cultural skills include: understanding the nature of culture and the fact that culture affects human behavior in his workplace; understanding the differences between cultures; understanding how cultural factors affect the organization of structures, systems and priorities; the ability to introduce elements of one culture to another; understanding how deeply elements of one culture can be introduced into another, and vice versa ${ }^{8}$.

Contraindications in the work of the international manager is ethnocentrism, that is, the desire to "fit" representatives of one culture into their own framework and expect them to meet these norms of behavior.

Human resources management of an organization operating in several countries, in a mixed or diverse cultural environment, aims to analyze the cultural impact on the main areas of organizational behavior and personnel management functions: organizational culture and structure; organizational communications; conflicts in the organization; staff motivation; selection and adaptation, training of personnel.

A manager who finds himself in an organization or in negotiations with representatives of an unfamiliar culture feels the need to obtain information for orientation. The source of information can be research, statistics, stories of experts on the one hand and their own experience - on the other. In cases where society is changing very quickly and the publication of research is not true, or when it is necessary to study the specific subculture of this society, the information about which is missing may require independent diagnosis of culture. A manager who works in a multicultural environment should be ready to fix non-competitive behavioral patterns for him when greeting, interacting with subordinates and management, resolving conflicts, motivation ${ }^{7}$.

The problems that arise in intercultural communication are primarily due to fact that the sender and the recipient of information interpret the same text in different ways, within different contexts.

Each culture has its own model of perfect communication, so the American style is characterized by "straightforwardness", which is not effective for all cultural contexts. In Japan, it is very common to avoid a direct statement of facts so that subordinates can avoid confrontation and "not lose their face". 
The choice of oral or written form for their communication is also guided by culture. Yes, English managers prefer written communication by e-mail. Most Ukrainian managers enter the neighboring department and negotiate with the partner personally, expecting more effect from personal communication. The Thai manager will send a report to his boss, but will talk to colleagues orally, expressing their feelings to them, which is important to him.

English-speaking cultures perceive a certain degree of conflict as a prerequisite for creativity and initiative. Tensions within the organization are considered as the norm and are a sign of a healthy organization. Well-managed disputes and discussions lead to "energy recharging" of participants and the emergence of new ideas. Cultures with the values of "deeds", in contrast to cultures with the values of "being", are more focused on conflict as a factor favorable to the creation of a new one, while cultures of the second type avoid conflict as a factor, destroying group harmony ${ }^{8}$.

Group decision-making in collectivist cultures usually takes much longer than in individualist cultures. The time was taken to make consensus, to reconcile the interests of all participants, then such a decision made by everyone is almost impossible to change.

Cross-cultural aspects of attracting, selecting and adapting personnel distinguish the following types of international policy in multinational companies: ethnocentric policy: filling key positions in their representative offices of the world only by personnel from the country of the parent company; polycentric policy: use of local residents to manage foreign representative offices and managers from the countries of the parent company as top managers of the company's headquarters; geocentric policy: to recruit the best and develop personnel, independent of nationality, to key positions in any multinational system.

In different countries, approaches to recruitment vary. U.S. and European multinationals typically use local managers and fewer expatriates in their foreign affiliates than Japanese.

The issue of choosing a local manager or expatriant to lead a branch should be resolved depending on number of factors - requirements for a single standardization of products, knowledge of local markets, etc ${ }^{8}$.

R. Selmer's research in Hong Kong showed that many local business owners like the leadership style of foreign managers in this order: the most desirable are American managers, then British, Japanese, and Asian managers in lost positions.

The price of the mistake of attracting an inappropriate specialist from expatriates to the top position in another country is very high. These are direct cash costs (costs range from 250 thousand to 1 million US dollars per expat to the top position, including wages, accommodation, maintenance of relatives), and broken careers, divorces, psychological injuries, etc. 
The involvement of a specialist can be unsuccessful not only due to incorrect assessment of his qualifications or experience, the process of cultural adaptation plays a decisive role. When they get into someone else's culture, foreigners get a culture shock.

Cultural shock is a person's response to new cultural living conditions, a certain psychological disorientation. It is accompanied by a feeling of tension and frusturation, energy decline, the need for solitary, depression.

A. Thorburn highlights 4 stages of culture shock:

1. "Honeymoon". You come to another country with a sense of excitement and uplift. You like everything new to the unusual.

2. Irritation and hostility. Your primary enthusiasm is subsiding. You start to notice differences. You cannot de-color small and serious problems.

3. Partial adoption of another culture. You begin to build your rules of life in this culture. You can differentiate between small and important problems again. You solve small problems.

4. Full acceptance. Adaptation to the cultural environment.

There are two areas of possible expat training: learning how to work in a given culture, and learning how to live in a given culture. It is best to combine these two topics into one training program. The training program may include the following sections:

1. Technical training - acquaintance with technologies used in the company's branches; local parameters in relation to these technologies.

2. Management training - acquaintance of the manager with his responsibilities in a new place, organizational structure and culture of the branch, communication channels between branches and the head office of the control system, business environment.

3. Cross-cultural training - acquaintance with the culture of the country, adaptation, learning to work and evaluation of achievements in this culture.

4. Language training.

At the same time, the stages of learning correspond to certain stages of rethinking cultural shock and changing intercultural sensitivity. Language and communication trainings take place at the stage of refusal. Training is necessary to understand cultural differences, corresponds to the stage of protection. The training of business cross-cultural skills corresponds to the stage of minimization. The training of specific working cross-cultural skills corresponds to the stage of acceptance of differences. The stage of adaptation is familiarity with the specifics of the country and culture. The integration stage corresponds to the training and support of expatriates. It is this training that will protect the manager from the consequences of cultural shock and prepare him for more constructive behavior in a foreign country ${ }^{7}$.

Conclusions from the study. The above-mentioned results of cross-cultural research and theoretical approaches developed by scientists from different 
countries can become the basis of both a practical directory for the Ukrainian manager and a program for teaching cross-cultural management in Ukrainian business schools.

\section{Psychological characteristics and their consideration in cross-cultural management}

We are witnessing the origin of economic ties between Ukraine and China, which is manifested in an increase in the volume of Chinese investments and an increase in the number of enterprises with Chinese capital in Ukraine, as well as in supplementing and interpetrating the Ukrainian and Chinese economies. China's sociocultural features affect not only the economic and political life of this country, but also certain countries, as well as the whole world, as Chinese enterprises and Chinese capital are more involved in the processes of globalization.

A number factors determine the need to take into account the phenomenon of cross-cultural management in the construction of business relations with Chinese companies ${ }^{7}$ :

- globalization of the world economy, in which representatives of different national cultures take part;

- increasing the number of business contacts on the world market among business representatives of different countries as a whole;

- expanding Chinese investments abroad and increasing production with Chinese capital and management in the world in particular;

- the need to improve the general culture of managers, both Ukrainian and Chinese, necessary to work in a cross-cultural environment;

- construction of a management system adapted to Ukrainian culture and mentality;

- improving the efficiency of the organization (production) on the basis of studying the experience of leading world companies;

- the emergence in some cases of the "cross-cultural side", caused by a misunderstanding of the features of another culture, lifestyle, mentality, ethnopsychological features of culture carriers of different countries, which may manifest themselves in joint production and in management decisions.

The following goals and objectives of cross-cultural management as a field of research and its practical application in the interaction of two cultures can be defined:

1) in the ability to negotiate with representatives of another culture;

2) in the ability to quickly resolve the conflict in a team where representatives of different cultures work;

3 ) in the ability to build a motivation system in companies where representatives of different cultures work;

4) in the ability to determine the necessary characteristics of leadership. 
Ethnocultural differences affect cross-cultural management. Cultural features are determined by the cultural environment, and ethnopsychological features - place of birth, ethnicity, place of residence ${ }^{8}$. These differences can be demonstrated by the example of interaction between representatives of the Western cultural tradition and Chinese cultural tradition or Confucian cultural tradition. China centric we call countries whose culture is largely determined by Confucian ethics - China, Korea, Vietnam, Japan.

In the modern conditions of the information society, the globalization of the world economy has significantly complicated business management, which in turn reduces the period necessary for making the right management decision. Managers need to have the latest data at the time of its adoption in order to make the optimal decision, and they must be processed and systematized. The technical capabilities of the information society help to solve this problem, which is reflected in the practice of control, which is a mechanism of information and analytical support of managers and managers of the company with the necessary data.

The control system integrates accounting, planning, marketing into a single self-managing system, which clearly defines the goals of the enterprise, management principles and means of their implementation. On this basis, the quality of management is significantly increased. Control is an important factor in ensuring the competitiveness of the enterprise, as it allows solving a number of issues related to and touching the stability of business and finance, search for possible internal reserves, prompt and strategic implementation of innovations, implementation of the mission, strategy for the development of the enterprise, etc.

The specifics of negotiations with representatives of Chinese centric culture are defined primarily by Confucian ethics and cultural tradition, which is fundamentally different from the Western European cultural tradition of negotiation. The impact of Confucian ethics on the culture and business tradition of negotiations is enormous. Confucian ethics forms a ritual - a set of correct patterns of behavior, including in course of business negotiations. Ritual and ethnopsychological features form methods of achieving the above key positions ${ }^{8}$ :

1. The authority of the parties in the Confucian tradition is determined by the age and status of the participant in the negotiations. Western cultural tradition is characterized by paying attention to experience, qualifications and competence. It is necessary to take part of equal-status partners in negotiations of different cultural groups.

2. Chinese tradition excludes direct conflict and aggression in relations, which is associated with the "ethics of the face". In this regard, "hard negotiations", the concept characteristic of the Western cultural tradition is not permissible. The Chinese side usually takes a passive wait-and-see 
position, responding to external calls. The conflict of the parties according to the Chinese tradition cannot be resolved in a direct confrontation. Unlike Western culture, where victory in open conflict is an achievement, a solution to the conflict in the Chinese sense, is possible only in course of reaching a compromise. In this regard, a huge role may be played by a third party or an intermediary involved in the settlement. This mediator must have authority for all parties to the negotiations.

3. How decisions are made is an important process that each party tries to understand. If rationality, calculation, forecast and planning are characteristic of the Western cultural tradition, then irrational and intuitive decision-making methods prevail in the Chinese business tradition, especially in conditions of uncertainty and risk. If the Western theory of management is based on the possibility of avoiding uncertainty in decision-making through forecasting and planning activities, then this is not peculiar to the Chinese tradition - only one person can decide.

4. It is necessary to note the increased scrupulousness to the details of negotiations and the content of the agreement by representatives of the Chinese cultural tradition, which is associated with the peculiarities of thinking from general to partial, while representatives of Western culture are prone to deduction - the formation of the overall picture from the details.

5. In accordance with general ideas, compromise - the terms of the agreement adopted by the parties because of negotiations. And if for the Western cultural tradition, a compromise is always the result of the agreements reached, but not always equivalent for both sides. For the Chinese cultural tradition, compromise is a mutually beneficial term of the agreement, only such in the future have the prospect of implementation.

6. Western cultural tradition attaches great importance to the contract as a written agreement between the parties enshrined in the Venn Convention on Treaties of 1980. The terms of the signed contract are inviolable and must be fulfilled under the fear of prosecution. However, when negotiating and concluding an agreement with the Chinese side, it is necessary to consider the worthlessness of contact and increased attention to oral arrangements, including personal contacts and guarantees in the Chinese cultural tradition.

7. Fulfillment of obligations under the agreement, based on the above, will depend on how the parties perceive the terms of the signed agreement and whether a compromise is found. The absence of such does not guarantee the terms of the agreement, even if there is a signed contract.

Domestic practice shows that market participants, business entities often make inefficient financial and investment decisions. The root cause of making irrational management decisions in the financial sphere and reducing the efficiency of financial and economic activities of agricultural enterprises as a whole is the uneven distribution of information between different groups of 
participants in financial relations. One of the effective tools for information support of management decision-making and an important element in ensuring the information function of control at the enterprise is financial diagnostics. The relevance of the research topic is due to the urgent need to improve methodological approaches to the diagnosis of enterprises and the need for further development of the domestic concept of control, taking into account the priority of the function of ensuring financial decision-making. In this sex, an attempt is made to analyze the effective criteria for assessing management ${ }^{5}$.

The experience of US universities reflects that in the last 15 years, students have demanded short-term educational programs devoted to the specifics of specific cultures (Japan, China, Indonesia, etc.). The active form of training and the mixed composition of participants create a unique environment of cross-cultural learning.

Ukrainian business schools gradually include theoretical courses in crosscultural management in the professional training and retraining of managers. A logical continuation of the development of business education programs is the development of practical short-term programs of cross-cultural training and educational assistance in the formation of cross-cultural skills of the manager.

Timely consideration of the above-mentioned ethnopsychological features allows to intensify the decision-making process in international business, the participants of which are representatives of Chinese and Ukrainian cultures. Systematic use of these indicators will significantly reduce the risks of crosscultural interaction, increase the effectiveness of adoption of managerial level. Like any type of organization, Chinese enterprises have their own strengths and weaknesses, and it is quite difficult to give an objective assessment of their activities. The advantages of such companies include a relatively high level of team connectivity, effective cooperation due to stable personal connections, low transaction costs, the ability to quickly respond to changes, the absence of the need for strict control of personnel and production. Among the shortcomings are the lack of initiatives and innovations among secondlevel subordinates and a clear strategy in management, a lack of professionalism, a constant threat to the division of personnel into factions that rival each other and limited opportunities for cooperation ${ }^{7}$.

Thus, the most significant feature of Chinese business cooperation is the general amorphousness of individual conglomerates of companies and the entire business web of the business community in the presence of a firm paternalistic host power in a predominantly family firm. This prevents the definition of credit ratings for Chinese corporations, as well as to obtain any information about the activities of individual Chinese entrepreneurs. The overwhelming importance of the general web of connections prevents the 
emergence of bright corporate brands in the Chinese business. All this is a feature of the Chinese management style, which must be taken account in the development of partnerships.

In today's environment of diversification and market differentiation, when the correct interpretation of marketing messages by the target audience is crucial, international communications are actively developing. Companies operating not only within their own countries, but also having access to international markets, face the need to develop a marketing strategy that takes account the individual characteristics of the target segment at the destination of the advertising message, as advertising is one of the most important and effective means of communication in modern marketing. Firms also need to take account the most important factors of the macro environment: the situation in the political environment, the peculiarities of the international market, current trends in the destination country and others. It is necessary to approach this issue from the point of view of an integrated approach, which includes the study of the existing advertising communications of rival enterprises, the choice of advertising media, the development of advertising circulation, planning and budgeting of the advertising campaign, the organization of advertising introduction into the media space, coordination and control of advertising activities and receiving feedback. Therefore, the most pressing problem of international advertising in today's environment is the choice between the strategy of its standardization or adaptation. Thus, over a 20-year period, from 2000 to 2020 , there has been an increase in research that refers to the dominance of cultural differences in consumer behavior. A. Poletaeva, PR manager of Soldis Communications (the largest advertising agency, Moscow) in her work "Adaptation of advertising messages" defined national culture as "a system of interconnected elements, in which you can distinguish several "nodes" - features that appear at all levels of advertising message: visual, semantic, conceptual and role-playing" .

They should be taken account when adapting an advertising message abroad. Thus, before choosing media speakers and developing a media plan, it is necessary to analyze the national features, values, interests and preferences of the destination market. In developed European countries, the common value is the social responsibility of business. In this regard, many companies on their online resources in the section "On the company" post information about the charitable activities of the organization. For example, Kraft Foods' website contains publications about the company's fight against hunger and indicates the size of donations. Panasonic's website publishes notes about the company's concern for the environment and its sponsorship of the Olympic Games. Therefore, when the Russian company enters the. It will be important for the foreign market not only to translate the text, but to adapt their communications, including the company's website, its content. 
As a negative example of the adaptation of advertising in the foreign market, we can distinguish the company in the fast food market KFC Holding. Launching its advertising in the UK, the fast food chain missed an extremely important point, which caused huge damage to the reputation of the brand in this market. A promotional video broadcast on local television showed people singing with their mouths full and eating at work. For sophisticated Englishmen, this behavior equates to insult. The advertising campaign caused a flurry of complaints about obscene advertising, because of which the commercial was quickly removed from the broadcast. KFC had to shoot and launch a new video in a short time but taking into account the requirements of the British market. An example of unrecorded linguistic adaptation is the largest American automotive corporation General Motors, which when the introduction of the Chevy Nova model to the South American market did not take account that in Spanish the name of the model - "Nova" - sounds like "will not go", so even an active advertising campaign could not increase sales in the Spanish-speaking market. Such cases are not only material, because updating advertising messages or launching completely new campaigns is costly. But the reputation and image of the organization are also damaged ${ }^{7}$.

The choice of media channels depends on the legislation and at the destination of the marketing message. For example, in China there are many prohibitions that are incomprehensible to the European. In this country, cinemas and television are prohibited from broadcasting time travel and films in the genre of fiction. Also, in China is very unprofitable advertising on television, because the cost of its placement is high enough, and opportunities for creativity are limited by strict censorship. It is for this reason that many firms prefer to place their advertising on the Internet, where there are no strict bans on advertising, or inflated prices for its placement. Therefore, when choosing a strategy to promote the product in the Chinese market, it is worth paying special attention to such a media channel as video advertising on the Internet, this format is especially popular and at the same time effective. In Africa, on the contrary, despite fact that in many countries, such as Nigeria, the spread of smartphones is rapid, the low level of development of the Internet itself and slow connection hinder the ability to watch videos online. In Tanzania and Zambia, there are predominantly simple phones that can only access "easy" web resources (such as the BBC website, the mobile phone version of Facebook and Wikipedia) and there is no way to watch movies or videos online.

\section{CONCLUSIONS}

To work in the modern market, companies must be flexible, intelligent, mobile, which, on the one hand, should provide, on the one hand, the possibility of continuous evolutionary adaptation of companies to market 
conditions and, on the other hand, the opportunity to make revolutionary and unexpected steps for competitors in their development that rapidly increase the competitiveness of the company. The latter is possible only on the basis of the process of continuous internal development (self-development) of the company.

A clear expression of belonging to the company is the top layer of organizational culture, which is based on behavioral norms, which are the basis of the values of the organization. The influence of organizational culture on the results is very significant - in case of non-compliance of organizational goals or its structure with the values and behavioral norms of employees, an internal conflict arises, which can develop into a deep crisis. Organizational culture evolves naturally under the influence of environmental changes and can be changed by management or another influential group of employees. On the basis of sociological researches of behavior motives, different schools have come to the same conclusion - a person in most cases tends to behave based primarily on his own interests and goals, as well as from his own vision of the worldview and his place in it. A person's personal goals and interests may coincide with the goals of the organization or vice versa are not related.

\section{SUMMARY}

The article provides subject areas of international, comparative and crosscultural management and defined tools for modeling cross-cultural interaction on the basis of tools of multi-agent systems. The basic principles of crosscultural management, which can be used when writing textbooks or in the work of managers, are analyzed. To implement management technologies today, the employee of the company must have cross-cultural achievements, that is, the ability in someone else's and mixed cultural environment to demonstrate consistent behavior that leads to achieving the goals. Crosscultural skills include: understanding the nature of culture and the fact that culture affects human behavior in its workplace; understanding the differences between cultures; understanding how cultural factors influence the organization of structures, systems and priorities; the ability to introduce elements of one culture to another; understanding how deeply elements of one culture can be introduced into another, and vice versa. Contraindications in the work of the international manager is ethnocentrism, that is, the desire to "fit" representatives of one culture into the framework of their own and expect them to be subject to these norms of behavior.

\section{REFERENCES}

1. Black J. and Mendenhall M. (1990), Cross-culture training effectiveness: a revive and theoretical framework for future research. Academy of Management Review, Vol. 15, P. 1131-1136. 
2. Evans S. (1992), Conflict can be positive. HR Magazine, Vol. 37 (5), pp. 49-51.

3. Laurent A. (1986), The Cross-cultural Puzzle of International Human Resources Management, Human Resources Management, Vol 25 (1), pp. 91-102.

4. Bunina V. (2008), Cross-cultural management and intercultural kommunikia, GUU, Vol'/24, pp. 34-45.

5. Holden N. (2005), Cross-cultural management. Conception of cognative management, Uniti-Dana, Vol. 6, pp. 364.

6. Petrushenko Yu (2009), Kros-kulturni aspekty povedinky u mizhnarodnomu biznesi [Cross-cultural aspects of improving the efficiency of international business], Bulletin of Khmelnitsky National University, Vol. 5. URL: http://www.market-infr.od.ua/journals/2021/53_2021/7.pdf (Accessed 17.09.2020).

7. Romanukha O. (2017), Rol kros-kulturnykh komunikatsii u menedzhmenti orhanizatsii [The role of cross-cultural communications in the management of organizations], Economics and society. Vol. 9. URL: https:// economyandsociety.in.ua/journals/9_ukr/103.pdf (Accessed 17.09.2020).

8. Kaplina A. and Kyrychenko N. (2020), Kros-kulturni aspekty upravlinnia personalom [Cross-cultural aspects of human resources management], Efektyvna ekonomika. Vol. 10 . available at: $\mathrm{http}: / / \mathrm{www} \cdot$.economy.nayka.com.ua/?op=1\&z=8258 (Accessed 03.11.2020).

\section{Information about the author: Kaplina Anastasiia Ivanivna, $\mathrm{PhD}$ in Economics,} Associate Professor at the Department of Management and Information Technologies Kherson State Agrarian and Economic University 23, Stritenska str., Kherson, Ukraine, 73006 orcid.org/0000-0001-6714-797X 